\title{
Synoptic environment associated with heavy rainfall events on the coastland of Northeast Brazil
}

\author{
P. T. Oliveira, K. C. Lima, and C. M. Santos e Silva \\ Universidade Federal do Rio Grande do Norte (UFRN), Programa de Pós-Graduação em Ciências Climáticas (PPGCC), \\ Natal, RN, Brazil
}

Correspondence to: P. T. Oliveira (priskateles@yahoo.com.br)

Received: 19 February 2013 - Revised: 10 June 2013 - Accepted: 11 June 2013 - Published: 10 July 2013

\begin{abstract}
Northeast Brazil (NEB) has an extensive coastal area, often hit by natural disasters that bring many social and economic losses. The objective of this work was to study the synoptic environment associated with a heavy rainfall event (HRE) on the coastland of NEB. We used daily rainfall data for coastal area of NEB between the states of Rio Grande do Norte and Bahia, divided into two subregions: north and south coastland. This data was obtained from the hydrometeorological network managed by the Agência Nacional de Águas and the daily data reanalysis from the ERAInterim. For the selection of HRE the technique of quantiles was used, thus defined HRE where at least one rain gauge recorded rainfall above 95th percentile. The interannual distribution of events showed occurrence maximum in La Niña years and minimal in El Niño years. The results suggest that the HRE were formed mainly due to the action of upper-level cyclonic vortex, in hight levels, and due to the action to South Atlantic convergence zone, in low levels.
\end{abstract}

\section{Introduction}

Northeast Brazil (NEB) exhibits an extensive coastal area in which different weather systems interact, which facilitates the occurrence of natural phenomena, such as a heavy rainfall event (HRE), that inflicts various social and economic losses on the affected areas. Scientific research within the climate modeling suggests that changes in the current climate are resulting in more frequent HRE and that human interference in the environment, such as deforestation of hillsides and construction in hazardous areas, has intensified the consequences of these events (Marengo, 2009). However, reliable estimates of trends for HRE are possible only for re- gions with a considerable number of rain gauges. The lack of long-term, high-quality observations, i.e. homogeneous, is the biggest obstacle for the quantification of extreme changes during the past century (Vincent et al., 2005; Haylock et al., 2006).

In addition to its importance in analyzing the behavior of HRE with respect to time, it is also important to know the factors that precede their formation and the dynamic conditions that support the development and maintenance of these events, as well as the characterization of the synoptic environment associated with HRE. To this end, some studies have been conducted (Teixeira and Satyamurty, 2007; Lima et al., 2010; Liebmann et al., 2011) by obtaining the anomaly composite of the atmospheric variables.

In this context, the objective of this paper is to characterize the synoptic environment associated with intense rainfall events, analyzing atmospheric disturbances related to this type of event, for different coastal regions of NEB.

\section{Data and methods}

\subsection{Data}

We used daily rainfall measurements of a set of 42 rain gauges distributed as seen in Fig. 1, the study area covers the coastal region between the states of Rio Grande do Norte and Bahia. This data was obtained from the hydrometeorological network managed by the Agência Nacional de Águas (ANA), from 1979 to 2002. This period was chosen due to the higher amount of rain gauges with the fewest number of flaws, resulting in a total of $5.5 \%$ of missing. 


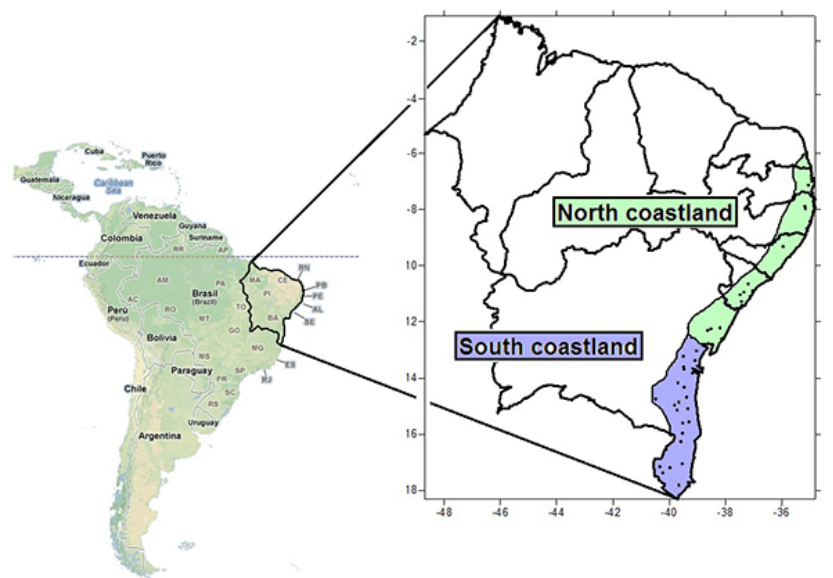

Fig. 1. The rain gauge spatial distribution (black dots) over the NEB coastland.

To characterize the synoptic environment associate with HREs, we used daily data reanalysis ERA Interim reanalysis (Dee et al., 2011), from the European Center for MediumRange Weather Forecasts (ECMWF). The ERA-Interim is the latest global atmospheric reanalysis produced by the ECMWF, which covers the period 1 January 1979 to the present and displays grid spacing of $1.5^{\circ}$ latitude $\times 1.5^{\circ}$ longitude. The meteorological variables used were zonal and meridional wind components, as well as geopotential and specific humidity, from 1979 to 2002.

\subsection{Cluster analysis}

We divide the dataset in two regions (north and south coastland) using the clustering analysis which presents different methods with different similarity measures of all elements to be grouped, usually expressed as a function of distance or metric.

We used the Ward hierarchical method, also used by Teixeira and Satyamurty (2011), and the Euclidean distance as the similarity measure, which according to Mimmack et al. (2001) is one of the measures listed for regionalization of climate data, also used by Fovell (1997), Marzban and Sandgathe (2006), Teixeira and Satyamurty (2011), among others.

To divide all of NEB in subregions, 151 rain gauges equally distributed throughout the region were used. To do the cluster analysis the climatology of the monthly totals of precipitation, from 1972 to 2002, was used as a variable in each rain gauge. Five subregions were obtained; two of them are located on the coast. The two regions situated on the coast were used in this paper; they are called the north coastland and the south coastland and cover a total of 42 rain gauges. To analyze the other three regions, different studies will be conducted.

\subsection{Dry and wet season}

The definition of dry and wet seasons was used for the seasonal climatology of each subregion. In the north coastland the dry season occurs during the summer (December, January and February (DJF)), presenting a climatological seasonal mean of $225 \mathrm{~mm}$, and the wet season occurs during the winter (June, July and August (JJA)), with climatological seasonal mean of $511 \mathrm{~mm}$. On the south coastland the dry season occurs during the winter (JJA), with a climatological seasonal mean of $228 \mathrm{~mm}$, and the wet season occurs during the summer (DJF), displaying climatological seasonal mean of $344 \mathrm{~mm}$. The dry and wet seasons of these two subregions are the exact opposite.

\subsection{Percentiles technique}

The HRE was defined based on the calculation of percentiles (Wilks, 2006) of the rainfall distribution considering only data from days with rainfall above zero. The HRE was defined as the event with precipitation above the 95th percentile. The percentile calculation was performed for each rain gauge individually.

To determine extreme events, many studies were developed in different regions using the distribution of daily rainfall percentiles. Groisman et al. (2005), Zhai et al. (2005) and Gemmer et al. (2011), used in general, the criteria of the 95th percentile to characterize HRE.

\subsection{Trend analysis}

The nonparametric Mann-Kendall (Mann, 1945; Kendall, 1975) test was applied to analyze the trend of the number and intensity of rainfall. This test compares each value of the temporal series with the remaining values in sequential order, counting the number of times that the remaining terms are greater than the analyzed value.

This test is the most appropriate method to analyze weather tendencies in climatological series and has been used to calculate climatic and hydrological tendencies (Silva, 2004; Cigizoglu et al., 2005; Sinha and Cherkauer, 2008; Santos et al., 2010; Acero et al., 2011). In applying the Mann-Kendall test, we used the sheet MAKESENS developed by Salmi et al. (2002).

\subsection{Composite anomaly}

After selection of events, fields of wind and geopotential anomaly composites for the day of the event, three days earlier and three days after were calculated to identify the dynamics and synoptic characteristics associated with episodes. However, we will present only the figures of the fields for the day of the event due to the small difference between this day and the other days. 


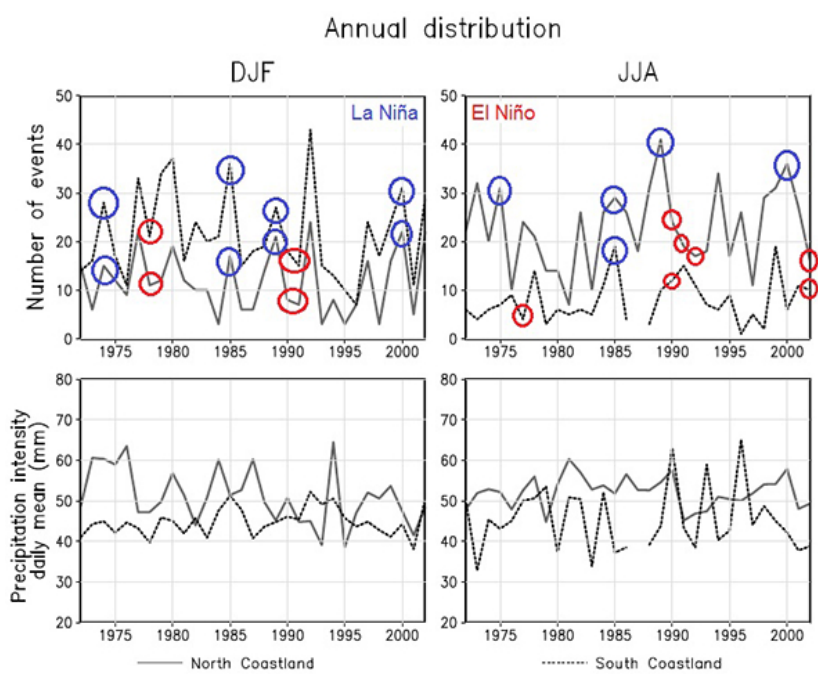

Fig. 2. Annual distribution of the number of EPI and precipitation intensity.

The field composed of a variable is obtained as follows:

$\bar{\emptyset}(x, y, p, D-n)=\frac{1}{N} \sum_{j=1}^{N} \emptyset(x, y, p, j, D-n)$,

where $\emptyset$ is the variable of the composite, $(x, y, p)$ denotes the spatial position of the variable, $N$ is the accounting of cases during the study period, $D-n$ is the $n$-th day preceding the event $(n=0,1,2,3)$, and the suffix $j$ refers to the $j$-th event.

We designate $\emptyset_{C}(x, y, p)$ to represent the climatology of the variable $\emptyset$. The composite anomaly $\left(\emptyset_{A}\right)$ is defined as

$\emptyset_{A}(x, y, p, D-n)=\bar{\emptyset}(x, y, p, D-n)-\emptyset_{C}(x, y, p)$.

\section{Results and discussion}

The distribution of the number of HREs and its daily intensity mean are shown in Fig. 2. During the period from 1972 to 2002, the HRE for the north coastland and the south coastland were respectively 364 and 236 for the dry season, and 707 and 664 for the wet season. The intensity of HREs in the two subregions showed the same value daily mean for the dry and wet seasons, $51.5 \mathrm{~mm}$ for the north coastland, and $45.5 \mathrm{~mm}$ the south coastland. The distribution interannual of the number of HRE showed negative a trend in summer (DJF) and a positive trend in winter (JJA) for the two subregions but without statistical significance, with a maximum in La Niña years and a minimum in El Niño years, most of the time. In relation to the intensity of the HRE, the north coastland showed negative trend during the two seasons, with $95 \%$ statistical significance only during the summer (DJF), while the south coastland showed positive trend during the summer (DJF) and negative during the winter (JJA), showing no significant statistical in any of the stations.
Figure 3 shows the wind and geopotential anomaly composite at $200 \mathrm{hPa}$ and $850 \mathrm{hPa}$ for the dry and wet seasons on the north coastland from 1979 to 2002. In the dry season, at $200 \mathrm{hPa}$ (Fig. 3a), there is a anomalous cyclonic circulation centered around $20^{\circ} \mathrm{W}, 5^{\circ} \mathrm{S}$, suggesting the upper-level cyclonic vortex (ULCV), which has its edge on the north coastland, is associated with strong a convection. The difference in geopotential shows the area of operation of the phenomenon. At $850 \mathrm{hPa}$ it can be verified that the region is under the influence of an anomalous cyclonic circulation. The trade winds are entering the continent and converging with winds from anomalous anticyclonic circulation, taking the northwest-southeast direction, so that the moisture in the region is transported in this direction. Moreover, in the wet season (Fig. 2b) at $200 \mathrm{hPa}$, strong winds blow in from the Amazon in a northwest-southeast direction. At $850 \mathrm{hPa}$, an anomalous anticyclonic circulation affects the study area, where the wind associated with this movement converge with the wind from the Atlantic Ocean, creating a wind confluence area that carries moisture to the north coastland of NEB.

The wind and geopotential anomaly composite at $200 \mathrm{hPa}$ and $850 \mathrm{hPa}$ for the dry and wet seasons of the south coastland during the period 1979 to 2002 are presented in Fig. 4. The dry season (Fig. 4a) at $200 \mathrm{hPa}$, shows a similarity to the rainy season of the north coastland, but with lighter winds. The level of $850 \mathrm{hPa}$ also shows a similarity to the wet season of the north coastland, but the high anomalous located around $40^{\circ} \mathrm{W}, 20^{\circ} \mathrm{S}$ is stronger due to the influence of an anticyclonic circulation at low latitudes. The wet season (Fig. 4b) also shows similarity to the dry season north coastland. At $200 \mathrm{hPa}$ there is a circulation that suggests a ULCV but is shifted more to the southwest, centered around $25^{\circ} \mathrm{W}, 7^{\circ} \mathrm{S}$, so that the edge of the ULCV is located above the south coastland. At $850 \mathrm{hPa}$, the anticyclone is more intense and stationary, centered around $22^{\circ} \mathrm{S}, 50^{\circ} \mathrm{W}$, suggesting a possible configuration of a South Atlantic convergence zone (SACZ), which is associated with intense convective activity in the edge, and as part of this edge is over the continent, there is a tendency for precipitation over the south coastland of NEB.

Figure 5 shows the mean moisture convergence between the levels $925 \mathrm{hPa}$ and $700 \mathrm{hPa}$, for the dry and the wet seasons of the two subregions. On the north coastland, the moisture convergence during the wet season has a lower concentration than in the dry season, while in the south coastland, the opposite occurs, the wet season has a higher concentration of moisture convergence. When investigating Fig. 2, we see that the north coastland has a higher amount of HREs in the wet season, but when we check the mean precipitation, the intensity of HREs are more extreme in the dry season, which can be explained by the higher intensity of convergence moisture in this period. Furthermore, the south coastland exhibits HREs in greater quantity and intensity during the wet season. 

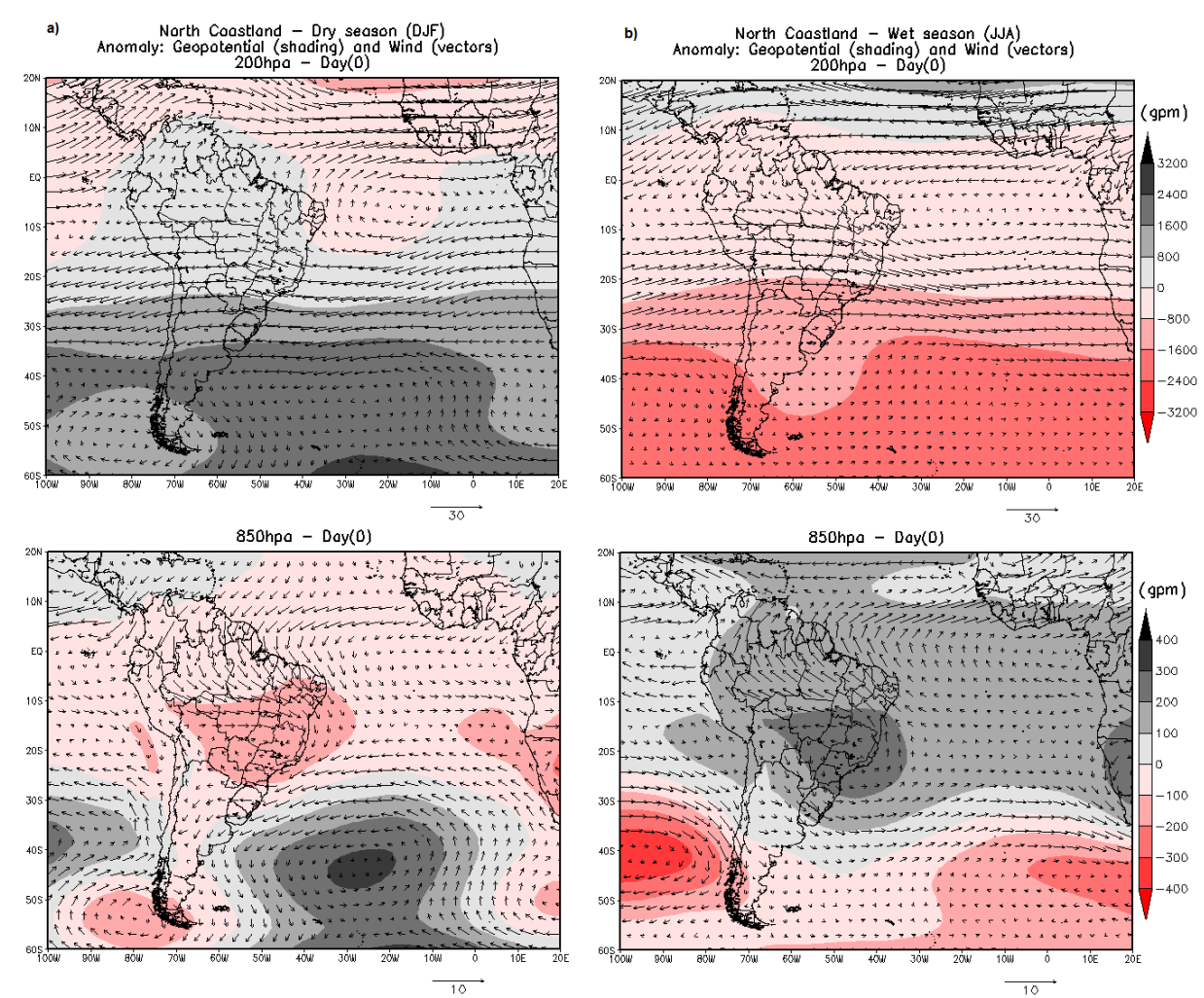

Fig. 3. Geopotential anomaly (shading) and wind anomaly (vectors) at $200 \mathrm{hPa}$ and $850 \mathrm{hPa}$ for the north coastland: (a) dry season and (b) wet season.
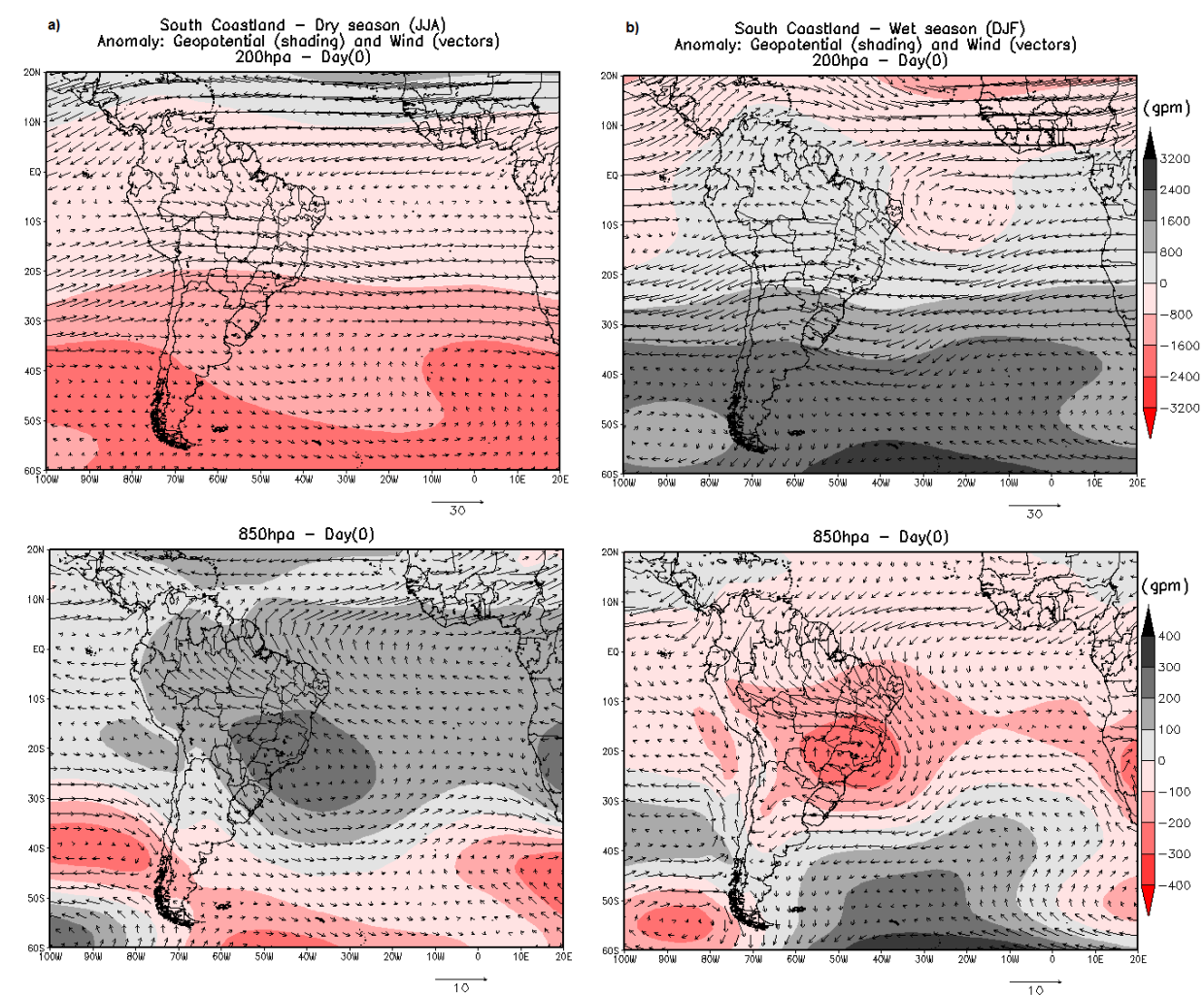

Fig. 4. Geopotential anomaly (shading) and wind anomaly (vectors) at $200 \mathrm{hPa}$ and $850 \mathrm{hPa}$ for the south coastland: (a) dry season and (b) wet season. 

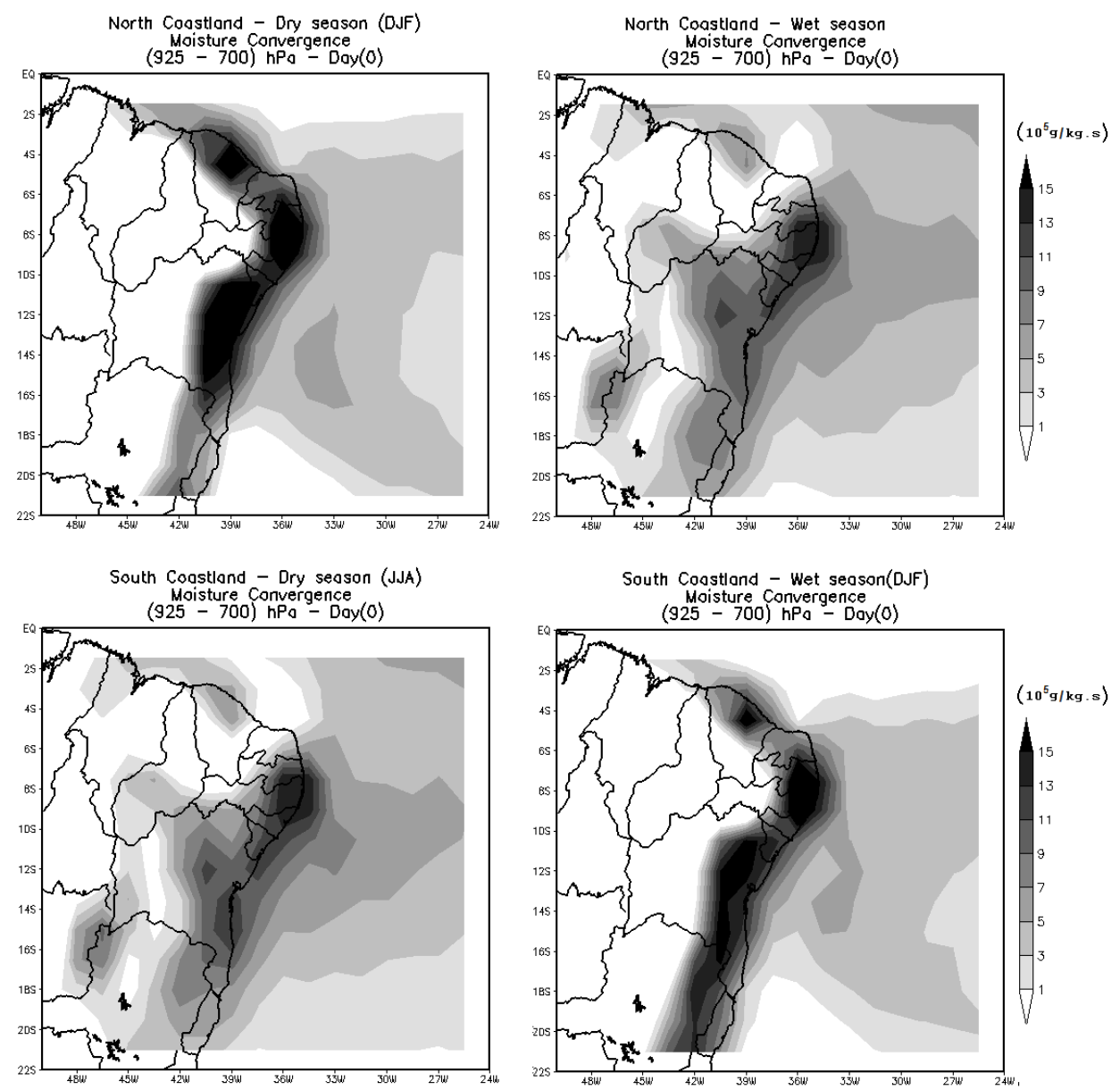

Fig. 5. Mean moisture convergence between the levels $925 \mathrm{hPa}$ and $700 \mathrm{hPa}$.

The pattern settings for the seasons DJF and JJA presented by Cavalcanti et al. (2002) show an anticyclone over the Atlantic Ocean and on the coast of NEB, and during JJA this anticyclone is found further west. With regard to the HRE configuration, there are differences in DJF and similarities in JJA, compared to Cavalcanti et al. (2002). This happen because there are opposite circulations during the two seasons.

\section{Conclusions}

The synoptic environment associated with HREs was different for each region, which was expected because the regions are different climatologically. The analysis of the anomaly composite for HREs showed compatibility with the systems formed at low levels for the north coastland: moisture transport to the coastland during the wet season and moisture transport to the southeast in the dry season, while the opposite occurred for the south coastland; thus, yielding circulations that contributed to the development and maintenance of convective activity. The north coastland showed higher amounts and greater intensity in HREs in its dry and wet sea- sons, in relation to the south coastland. The amount of HREs was lower in the dry season for both subregions and higher in the wet season. However, the intensity of the HREs was stronger during the dry period in the north coastland, which can be explained by the higher concentration of moisture in this season.

Interesting to note that both subregions are exactly opposite each other, i.e. the dry season occurs in one subregion in the same period that the wet season occurs in the other. Thus, the mechanisms that were responsible for creating a dry subregion, consequently made another subregion wet. For the dry season of the north coastland these mechanisms are the confluence between the trade winds and the winds from the anomalous anticyclonic circulation, causing the wet season in the other subregion. For the dry season of the south coastland they are the wind confluence from the anomalous anticyclonic circulation and the winds that come from the Atlantic Ocean, these mechanisms are responsible for the wet season on the north coastland.

The results suggest that on the north coastland, during the dry season, HREs were formed mainly due to the actions of ULCV, while during the wet season, HREs were formed 
mainly by the moisture transported from the Amazon that was redirected to this subregion due to one confluence zone of winds in the southeast-northwest direction. This same mechanism was responsible for the formation of HREs in the south coastland in the dry season, while in the wet season, the results suggest the occurrence of two phenomena: the ULCV and SACZ. According to Lima et al. (2010), the formation of HREs in southeastern Brazil are associated with the SACZ that is a major precipitating phenomena in the region due to the fact that the coverage of this phenomenon often reaches much of northern Bahia.

Acknowledgements. To the Coordenação de Aperfeiçoamento de Pessoal de Nível Superior (CAPES) by doctoral scholarship of the first author, P. T. Oliveira, and to the Agência Nacional de Águas (ANA) by rainfall daily data.

Edited by: K. Tokeshi

Reviewed by: two anonymous referees

\section{References}

Acero, F. J., Gallego, M. C., and García, J. A.: Multi-day rainfall trends over the Iberian Peninsula, Theor. Appl. Climatol., 108, 411-423, 2011.

Cavalcanti, I. F. A., Marengo, J. A., Satyamurty, P., Nobre, C. A., Trosnikov, I., Bonatti, J. P., Manzi, A. O., Tarasova, T., Pezzi, L. P., D'almeida, C., Sampaio, G., Castro, C. C., Sanches, M. B., and Camargo, H.: Global Climatological Features in a Simulation Using the CPTEC-COLA AGCM, J. Climate, 15, 29652988, 2002.

Cigizoglu, H. K., Bayazit, M., and Önöz, B.: Trends in the maximum, mean, and low flows of Turkish Rivers, J. Hydrometeorol., 6, 280-290, 2005.

Dee, D. P., Uppala, S. M., Simmons, A. J., Berrisford, P., Poli, P., Kobayashi, S., Andrae, U., Balmaseda, M. A., Balsamo, G., Bauer, P., Bechtold, P., Beljaars, A. C. M., Van De Berg, L., Bidlot, J., Bormann, N., Delsol, C., Dragani, R., Fuentes, M., Geer, A. J., Haimberger, L., Healy, S. B., Hersbach, H., Hólm, E. V., Isaksen, L., Kallberg, P., Köhler, M., Matricardi, M., Mcnally, A. P., Monge-Sanz, B. M., Morcrette, J. J., Park, B. K., Peubey, C., De Rosnay, P., Tavolato, C., Thépaut, J. N., and Vitart, F.: The Era-Interim reanalysis: configuration and performance of the data assimilation system, Q. J. Roy. Meteor. Soc., 137, 553-597, 2011.

Fovell, R. G.: Consensus clustering of u.s. temperature and precipitation data, J. Climate, 10, 1405-1427, 1997.

Gemmer, M., Fischer, T., Jiang, T., Su, B., and Liu, L. L.: Trends in precipitation extremes in the Zhujiang River Basin, South China, J. Climate, 24, 750-761, 2011.

Groisman, P. Y., Knight, R. W., Easterling, D. R., Karl, T. R., Hegerl, G. C., and Razuvaev, V. N.: Trends in intense precipitation in the climate record, J. Climate, 18, 1326-1350, 2005.

Haylock, M. R., Peterson, T. C., Alves, L. M., Ambrizzi, T., Anunciação, Y. M. T., Baez, J., Barros, V. R., Berlato, M. A., Bidegain, M., Coronel, G., Corradi, V., Garcia, V. J., Grimm, A. M., Karoly, D., Marengo, J. A., Marino, M. B., Moncunill, D.
F., Nechet, D., Quintana, J., Rebello, E., Rusticucci, M., Santos, J. L., Trebejo, I., and Vincent: Trends in Total and Extreme South American Rainfall in 1960-2000 and Links with Sea Surface Temperature, J. Climate, 19, 1490-1512, 2006.

Kendall, M. G.: Rank Correlation Methods, London, Charles Griffin, 120 pp., 1975.

Liebmann, B., Kiladis, G. N., Allured, D., Vera, C. S., Jones, C., Carvalho, L. M. V., Bladé, I., and Gonzáles, P. L. M.: Mechanisms associated with large daily rainfall events in Northeast Brazil, J. Climate, 24, 376-396, 2011.

Lima, K. C., Satyamurty, P., and Fernández, J. P. R.: Large-scale atmospheric conditions associated with heavy rainfall episodes in southeast Brazil, Theor. Appl. Climatol., 101, 121-135, 2010.

Mann, H. B.: Nonparametric tests against trend, Econometrica, 13, 245-259, 1945.

Marengo, J. A.: Mudanças climáticas, condições meteorológicas extremas e eventos climáticos no Brasil, Mudanças Climáticas e Eventos Extremos no Brasil. Fundação brasileira para o desenvolvimento sustentável - fbds, 4-18, 2009.

Marzban, C. and Sandgathe, S.: Cluster analysis for verification of precipitation fields, Weather Forecast., 21, 824-838, 2006.

Mimmack, G. M., Mason, S. J., and Galpin, J. S.: Choice of distance matrices in cluster analysis: defining regions, J. Climate, 14, 2790-2797, 2001.

Salmi, T., Määttä, A., Anttila, P., Ruoho-Airola, T., and Amnell, T. Detecting Trends of Annual Values of Atmospheric Pollutants by the Mann-Kendall Test and Sen's Slope Estimates - The Excel Template Application MAKESENS, Publication on Air Quality, Finnish Meteorological Institute, 31, 2002.

Santos, D. S., Silva, V. P. R., Sousa, F. A. S., and Silva, R. A.: Estudos de alguns cenários climáticos para o Nordeste do Brasil, Revista Brasileira de Engenharia Agrícola e Ambiental, 14, 492500, 2010.

Silva, V. P. R.: On climate variability in Northeast of Brazil, J. Arid Environ., 58, 575-596, 2004.

Sinha, T. and Cherkauer, K. A.: Time series analysis of soil freeze and thaw processes in Indiana, J. Hydrometeorol., 9, 936-950, 2008.

Teixeira, M. S. and Satyamurty, P.: Dynamical and synoptic characteristics of heavy rainfall episodes in Southern Brazil, Mon. Weather Rev., 135, 598-617, 2007.

Teixeira, M. S. and Satyamurty, P.: Trends in the frequency of intense precipitation events in Southern and Southeastern Brazil during 1960-2004, J. Climate, 24, 1913-1921, 2011.

Vincent, L. A., Peterson, T. C., Barros, V. R., Marino, M. B., Rusticucci, M., Carrasco, G., Ramirez, E., Alves, L. M., Ambrizzi, T., Berlato, M. A., Grimm, A. M., Marengo, J. A., Molion, L., Moncunill, D. F., Rebello, E., Anunciação, Y. M. T., Quintana, J., Santos, J. L., Baez, J., Coronel, G., Garcia, J., Trebejo, I., Bidegain, M., Haylock, M. R., and Karoly, D.: Observed Trends in Indices of Daily Temperature Extremes in South America 1960 2000, J. Climate, 18, 5011-5023, 2005.

Wilks, D. S.: Statistical Methods in the Atmospheric Sciences, 2nd Edn., Amsterdam, Elsevier Academic Press 627 pp., 2006.

Zhai, P., Zhang, X., Wan, H., and Pan, X.: Trends in total precipitation and frequency of daily precipitation extremes over China, J. Climate, 18, 1096-1108, 2005. 